\title{
IMPLEMENTASI PANCASILA TANTANGAN DAN SOLUSINYA
}

\author{
oleh \\ BAMBANG SUGIANTO, LA TAENA, LA BILU \\ Dosen Fakultas Keguruan dan Ilmu Pendidikan Universitas Halu Oleo \\ Email: labilu_fkip@uho.ac.id
}

\begin{abstract}
ABSTRAK
Neoimperialisme masih beroperasi di berbagai bagian dunia dengan segala cara, halus maupun kasar tergantung situasional menguntungkan pihak yang kuat, sementara yang lemah tetap dieksploitasi dalam ungkapan lain gambaran sila kedua pancasila tentang suasana hidup global yang berupa kemanusiaan yang adil dan beradab, tampaknya masih belum segera menjadi kenyataan. Menghadapi persoalan mendasar ini, kita harus memiliki kepekaan sejarah dan kepekaan nurani dalam membaca dinamika kehidupan global, nasional, dan lokal yang berubah dengan cepat. Pancasila akan mampu memberikan sebuah Ontological Security (Human Ontology) kepada kita semua di masa yang akan datang. Pancasila dengan seluruh aspeknya memberikan landasan yang amat kuat bagi peningkatan kemampuan profesionalisme, peningkatan cinta tanah air, peningkatan iman dan taqwa terhadap Tuhan Yang Maha Esa, yang disertai sikap keterbukaan, sikap kebersamaan, toleransi, serta sikap harmoni.
\end{abstract}

\section{Kata Kunci: Implementasi Pancasila, Tantangan, Solusi}

\section{PENGANTAR}

Persoalan krusial yang mendesak adalah beberapa diantara penduduk bumi ini yang benar-benar punya kepekaan terhadap masalah lingkungan yang dari waktu ke waktu mengalami proses pencemaran kuantitatif dan kualitatif sekaligus. Nusantara, bumi Pancasila tercinta ini juga tidak bebas dari perlakuan rakus dan tidak bertanggung jawab yang dilakukan oleh sementara orang demi menguras kekayaan dan memuaskan nafsu duniawinya. Pasal 33 UUD 1945 sering benar dilecehkan begitu saja. Sudah cukup lama bumi ini tidak mau lagi tersenyum ramah kepada penghuninya akibat derita luka dikulitnya yang semakin parah. Lapisan ozon sudah mulai tersobek, cuaca dibumi sudah semakin memanas, dan sebagai akibat adanya lubang-lubang pada ozon itu ialah cahaya ultraviolet matahari akan lebih leluasa memancar ke bumi dengan segala akibat buruknya bagi kehidupan manusia. Begitu juga lingkungan politik dan ekonomi, dunia jauh dari suasana adil. Bentuk-bentuk neoimperialisme masih beroperasi diberbagai bagian dunia dengan segala cara, halus maupun kasar, tergantung situasi, asal menguntungkan pihak yang kuat, sementara yang lemah tetap saja dieksploitasi. Dalam ungkapan lain gambaran sila kedua Pancasila tentang suasana hidup global yang berupa kemanusiaan yang adil dan beradab, tampaknya masih belum segera menjadi kenyataan. 
Sementara itu dalam negeri sendiri, sila ini dicerminkan oleh budaya kekerasan, brutalitas, kolusi dan korupsi, praktik penggundulan hutan yang semakin akut dari waktu ke waktu. Dengan pendahuluan ini penulis meminjam pemikiran Ahmad Syafii Maarif $^{1}$ dalam membahas substansi tulisan ini. Penulis ingin melihat Pancasila tidak hanya berhenti sebagai pure conceptyang mengawang-awang, tetapi punya nilai praksis untuk menyelamatkan masa depan bangsa ini dari segala bentuk perbuatan yang tidak beradab serta tegaknya keadilan secara merata dalam kehidupan berbangsa dan bernegara.

\section{PANCASILA DAN PERADABAN MODERN}

Sebelum memasuki pembicaraan tentang Pancasila ada baiknya kita melihat selintas asal usul peradaban modern yang kini sedang berada di atas angin. Landasan filofis teori pengetahuan dan peradaban modern ditegakkan atas sebuah postulat "cogito ergo sum" (saya berpikir, oleh sebab itu saya ada). Postulat ini adalah inti dari teori ilmu pengetahuan Rene Descartes (1596-1650) dan memuat segala yang terpenting dalam sistem filsafatnya ${ }^{2}$. Postulat cogito yang dikaitkan dengan konsep keberadaan manusia ternyata punya dampak yang dasyat bagi perkembangan filsafat dan ilmu pengetahuan modern. Kalau Thomas

${ }^{1}$ Ahmad Syafii Maarif, Pancasila, Sejarah, dan Perkisaran Abad M enjelang Milenium ke-3 dalam Jurnal Pusat Studi Pancasila Universitas Gadjah Mada No. 1. Th 1 Juli 1997. HIm. 29-32 dan 35-36.

${ }^{2}$ Lihat Rene Descartes. Discourse on M ethod and the Meditation. Terj. F.E. Sutclife. New York: Penguin Books. 1976, hlm 18-19 dan 53.
Aquinas (1225-1274), filosof sekaligus membedakan antara kearifan filosofis dengan kearifan teologis, namun ia masih ingin menyatukannya. Descartes bukan saja membedakannya tetapi memisahkannya sama sekali. ${ }^{3}$ Maka munculah dua kearifan yag dalam perjalanan waktu bergerak kearah dua kutub yang saling menjauh satu sama lain. Descartes bahkan berpendapat pada sistem kosmos sama sekali tidak ditemukan jejak tuhan, seperti diungkapkan Karen Amstrong "he found the cosmos completely Godless." 4 Dalam kalimat lain, kepada dunia modern telah dikenal dua tipe kearifan: kearifan filosofis yang sekuler dan kearifan yang berdasarkan iman sekali Descartes sendiri sebenarnya adalah seorang pemeluk Katolik yang taat. Apa yang terjadi berikutnya adalah split antara otak dan hati, perseteruan antara filsafat dan iman. Mana yang unggul?

Dalam sejarah peradaban modern selama lebih tiga ratus tahun, iman berada pada posisi kalah dan tertindas dengan segala akibat buruknya dalam sikap dan pilihan moral manusia. "jika tidak ada tuhan, segala menjadi mungkin," demikian ungkapan kegelisahan yang dilontarkan Dostoevski ketika menyaksikan kerapuhan fondasi spiritual manusia modern. $^{5}$ Peradaban cogito memang lebih memungkinkan how(bagaimana) daripada why (mengapa). How menyangkut persoalan teknis, why berkaitan dengan persoalan moral, motivasi dan niat dasar. Apa yang

\footnotetext{
${ }^{3}$ Etience Gilson. God and PhilosophyNew Heven and London: Yale University Press. 1969. HIm 77.

${ }^{4}$ Karen Amstrong, " A History of God, New York: Alfred A Knopf. 1993. HIm 300.

${ }^{5}$ Lihat Erich Fromm. The Revolution of Hope. New York: Harper \& Row. 1968 hlm 134
} 
mungkin dilakukan secara teknis harus dilakukan tanpa mengingat secara mendalam akibat buruk yang dapat terjadi. Pembuatan bom nuklir adalah contoh yang paling mengerikan.

Sejak Descartes Barat tidak punya minat lagi untuk merenungkan secara mendalam masalah why karena terfokus dan terkurasnya perhatian mereka pada masalah how, tulis Roger Garaudy beberapa tahun yang lalu. ${ }^{6}$ Hasilnya memang luar biasa: ilmu dan teknologi berkembang sangat pesat. Berkat penguasaan hukum-hukum alam bumi dan bagian-bagian lain dari alam semesta telah dieksploitasi secara besarbesaran dengan dana ratusan bilion dolar. Perkara lingkungan yang rusak, kemiskinan, keterbelakangan dan kebdohan yang masih diderita oleh sekitar 2/3 umat manusia dimuka bumi, tidak perlu dirisaukan karena itu semua diluar kepentingan how. Bahkan diharapkan agar negara-negara miskin itu tetap saja tergantung kepada negaranegara berteknologi maju untuk selama lamanya. Inilah sebenarnya salah satu bentuk neoimperialisme yang baru saja kita singgung. Peran ini tampak jelas dalam politik luar negeri Amerika Serikat sejak perang dingin dan sesudahnya.

George Kennan sebagai perumus politik pembendungan (containment policy) terhadap kounisme, percaya bahwa Amerika adalah pengawa, peradaban barat dan sekaligus bersama Eropa memimpin dunia, "dalam otaknya tidak diragukan lagi," tulis Edward W. Said," bahwa eropa dan Amerika secara unit telah diposisikan untuk memimpin dunia, suatu pendangan yang menyebabkannya

${ }^{6}$ Lihat Roger Graudy "The Balance Sheet of Wester Philosophy", Al-Nahda. Vol 4 No 3. 1984/1404, 14. menganggap negeri sendiri semacam remaja yang sedang tumbuh menuju yang dulu dimainkan oleh imperium Brytania Raya. ${ }^{7}$ Angan-angan romantis yang bercorak imperialistik ini tampaknya tetap terpeihara dalam benak orang barat, khususnya Amerika, Ingris dan Prancis. Keagungan imperialisme, ini diposisikan kembali kepada masa modern melalui berbagai metode dan rekayasa. Amerika sendiri sebenarnya adalah bangsa Imperialis kesiangan, muncul pada saat tata dunis telah mengalami perubahan dtastis dari era konialisme ke era kemerdekaan. Sekiranya negara adikuasa ini punya kearifan sejarah, seharusnya ambisi untuk meniru imperium Britania Raya Kuno sama dengan memutar jarum jam ke belakang.

Dalam situasi dunia yang dililit oleh rantai kepincangan dan ketidakadilan itu, solusi dan prinsipprinsip moral yang bagaimana kira-kira yang mungkin ditawarkan Pancasila untuk merakit sebuah masa depan yang lebih adil dan beradab? Sukar bagi kita untuk menjawab pertanyaan seperti ini, karena Pancasila itu sendiri sampai batas-batas yang jauh baru berhasil menepis isu negara Islam atau Komunis. Dalam persoalan ini Pancasila memang telah berfungsi sangat efektif, dan kita wajib bersyukur karena secara teoritik konflik ideologis yang dapat memecah belah bangsa telah dapat dihindari. Kini tidak muncul lagi gelombang besar kekuatan politik kita yang tidak menerima Pancasila sebagai dasar filosofis dan ideologi negara. Dengan kenyataan ini harapan Bung Karno untuk melihat Pancasila sebagai dasar negara agar bersifat abadi mungkin tidak ada persoalan dimasa

${ }^{7}$ Edwar W. Said, Culture and Imperialism. New York: Alfredl A. Knopf. 1993, hlm 285. 
depan. "Tetapi dasarnya, isinya Indonesia yang merdeka dan kekal abadi menurut pendapat saya haruslah Pancasila" kata Bung Karno pada 1 Juni 1945. "Itulah harus Weltanschauung kita".

Pelaksanaan sila ke lima dalam kehidupan konkrit masih jauh dari citacita yang digariskan para pendiri negara. Kegalauan sistem nilai yang sangat berat kita rasakan sekarang ini adalah pertanda bahwa nilai praksis Pancasila masih belum hidup bersama kita. Jika masih demikian kenyataannya, bagaimana kita akan punya wibawa untuk menawarkan Pancasila sebagai panacea bagi susunan dunia yang serba zalim dan pinang ini, sementara kepentingan itu juga sedang menghimpit kita di tanah air? Borokborok korupsi dan kerasukan ekonomi semakin hari semakin mengganas, menggerogoti urat nadi bangsa ini dari hari ke hari, seakan akan Pancasila telah kehabisan tenaga menghadapinya. Inilah diantara fenomena bangsa Indonesia modern yang menyesakkan nafsu kita semua.

Bahwa Pancasila dapat dikembangkan menjadi sistem moral universal, penulis tidak meragukannya. Dipayungi oleh sila pertama, Ketuhanan Yang Maha Esasebagai sumber nilai sila-sila yang lain dan ditutupi oleh sila keadilan sosial sebagai tujuan kemerdekaan,Pancasila punya peluang untuk ditawarkan sebagai Weltanschauung yang mendunia. Tetapi kelima sila hendaknya jangan diperas menjadi Trisila atau bahkan Ekasila (gotong royong, sebagaimana Bung Karno pernah menawarkan pula dalam pidatonya di atas. ${ }^{8}$

${ }^{8}$ Lihat Soekarno, Lahirnya Pancasila, Jakarta: Bwaro Niaga, 1962. HIm 28-30
Biarkanlah Pancasila itu bertahan dengan kelima silanya. Sebab bila diperas-peras sila ketuhanan dan silasila yang lain akan terkubur dalam epitet gotong royong. Cara semacam ini tentu sangat berbahaya, sebab Pancasila akan terjatuh ke dalam sekularisme. Setidak-tidaknya dalam perasan gotong royong, sila-sila yang lain akan kehilangan identitasnya, sesuatu yang rapuh bagi suatu sistem filsafat kenegaraan. Kita ingin yang kukuh bukan yang rapuh dengan cara peras memeras itu! Oleh sebab itu, sekalipun Bung Karno yang pertama kali mengucapkan pidato tentang Pancasila, tawarannya tentang kemungkinan pengerutan sila-silanya harus ditolak dengan tegas, sebab cara itu akan membunuh Pancasila itu sendiri. Masalah ini sangat mendasar. Oleh sebab itu, orang harus berpikir seribukali sebelum memeras Pancasila. Dan di atas itu semua, tanpa intervensi wahyu Pancasila akan kehilangan bentuk.

\section{TANTANGAN DI DEPAN PANCASILA}

Bagaimana Pancasila menghadapi persoalan mendasar di atas? Peradaban modern seperti dilihat Toynbee sudah tidak punya tawaran apa-apa untuk menjawab pertanyaan itu. Mengenai Pancasila apakah punya sesuatu untuk ditawarkan akan sangat tergantung kepada proposisi ini: apakah Pancasila mau mengundang wahyu untuk menafsirkan dan menyinari dirinya atau Pancasila itu semata-mata berdasarkan faktor sejarah dan sosiologis masyarakat Indonesia saja? Jika Pancasila hendak dijadikan sebuah sistem filsafat yang utuh dan komprehensif, maka kita harus 
menjawab persoalan krusial berikut terlebih dahulu.

Pertama, harus didudukan secara jelas hubungan spiritual sila pertama berupa Ketuhanan Yang Maha Esa dengan wahyu. Apakah konsep ketuhanan dalam Pancasila memerlukan wahyu untuk memehami atau berikan saja kebebasan kepada setiap orang untuk "membentuk" Tuhan berdasarkan kesadaran kemanusiannya masingmasing seperti pendapat Descartes? Corak jawaban yang diberikan terhadap pertanyaan pertama ini akan menentukan corak hubungan agama dengan sila-sila yang lain. Ungkapan "agama tidak akan dipancasilakan dan Pancasila tidak akan diagamakan" tampaknya lebih merupakan terma (istilah) politik tinimbang terma filsafat.

Kedua, harus disepakati bahwa sila-sila dalam Pancasila itu merupakan satu kesatuan dengan sila pertama sebagai komandannya. Jika persoalan mendasar ini tidak ada kejelasannya, maka Pancasila yang hendak dijadikan sistem filsafat itu masih akan mengundang pertanyaan-pertanyaan yang sulit dijawab.

Ketiga, nilai praksis Pancasila harus mampu mengikat dan mencoraki prilaku setiap warga negara Indonesia secara efektif. Karena itu sistem dan pelaksanaan hukum sebagai penjabaran nilai-nilai Pancasila itu harus jelas dan tegas, sehingga rasa keadilan rakyat tidak menjadi bulan-bulanan seperti yang sering berlaku selama ini. Kalau nilai praksis ini tidak menjadi kenyataan, maka tidak ada jaminan bahwa Pancasila pasti selamat di masa depan. Bagi penulis praksisme Pancasila itu sudah sangat mendesak dan mutlak untuk dilaksanakan. Marxisme digiring ketiang gantungan sejarah adalah karena kegagalannya menjawab jeritan nurani manusia untuk mendapatkan keadilan dan untuk diakui sebagai manusia penuh (full human).

Akhirnya terpulang pada bangsa ini, apakah kita punya kepekaan sejarah dan kepekaan nurani dalam membaca dinamika kehidupan global dan kehidupan nasional yang berubah dengan cepat pada saat melintasi masa transisi memasuki milenium ke-3 yang cukup kritis ini untuk membuat masa depan yang lebih adil, anggun, dan ramah. Kita berharap bahwa kepekaan itu masih bersama kita sekalipun sering ditindas oleh kerakusan komersial dan sikap mementingkan diri sendiri, sesuatu yang bertentangan secara diametral dengan seluruh nilai Pancasila. Pilihan bagi sebuah masa depan bangsa harus diputuskan sekarang. Pancasila akan mampu memberikan sebuah ontological security (keamanan onotologis) kepada kita semua di masa yang akan datang.

\section{SOLUSI YANG DITAWARKAN}

Generasi muda perlu memahami semua ini, bahwa Pacasila dengan seluruh aspeknya memberikan landasan yang amat kuat bagi peningkatan kemampuan profesionalisme, peningkatan cintah tanah air, dan peningkatan iman dan taqwa terhadap Tuhan Yang Maha Esa, yang disertai sikap keterbukaan, sikap kebersamaan, dan sikap kemitraan, serta sikap harmoni

\section{Kemampuan Profesional Yang Tinggi}

Sifat tantangan yang dihadapi masa kini mengharuskan adanya profesionalisme di masing-masing bidang untuk 
menanganinya. Dengan adanya globalisasi yang membawa keterbukaan di bidang ekonomi dengan segala implikasi persaingannya, penanganan masalah tidak dapat dilakukan secara amatiristis dan bersifat coba-coba. Apabila kemampuan profesionalisme ini tidak diperhatikan, yang mengakibatkan kita tidak dapat bersaing dengan perusahaan asing yang terbuka masuk ke dunia usaha Indonesia dengan segala kecanggihannya, kita akan tertinggal dan menjadi penonton di Tanah Air sendiri.

Profesionalisme di tingkat menengah diperoleh melalui pendidikan kejuruan pada sekolah menengah, dan pendidikan tinggi melalui program Diploma, Sarjana (S1, S2, dan S3) maupun pendidikan non-gelar yang memberikan keterampilan yang diperlukan (spesialisasi). Pendidikan yang diberikan untuk meningkatkan profesionalisme di tingkat menengah dan tingkat tinggi ini harus memapu mengantisipasi kebutuhan akan keahlian dan keterampilan tertentu. Hal ini diperlukan dalam menghadapi persaingan bebas tersebut di atas, sehingga tidak boleh terpaku pada pendekatan konvensional di bidang pendidikan dengan hanya melihat kepada kebutuhan nasional dalam arti sempit.

\section{Cinta Tanah Air}

Sebagaimana generasi-generasi terdahulu berperan dalam menghadapi tantangan amannya atas dasar rasa cinta tanah air yang mendalam, yang memberikan motivasi kuat untuk berjuang, maka rasa cinta Tanah Air yang mendalam ini juga menjadi motivasi bagi generasi muda sekarang dalam berjuang menghadapi tantangan zaman yang rumit ini. Terutama generasi muda 1945, dengan semangat juangnya yang tak kunjung padam, telah menghadapi tantangannya di masa revolusi fisik dengan pengorbanan jiwa dan raga dalam skala besar. Makam para pemuda generasi 1945 yang tersebar di seluruh Tanah Air, baik yang ada di Taman Pahlawan, maupun di tempat-tempat lain, merupakan bukti keikhlasan berbakti kepada Tanah Air yang tiada ternilai harganya.

Semangat juang 1945 yang didasarkan cintah Tanah Air yang mendalam telah memberikan motivasi untuk merebut dan mengisi kemerdekaan dengan perjuangan penuh keikhlasan. Nilai-nilai 1945 itu telah memberikan motivasi kepada generasi penerus untuk dengan cinta Tanah Air yang mendalam pula, meneruskan perjuangan yang wujudnya ditentukan oleh tatangan zaman.

Globalisasi membawa
konsekuensi berupa terbukanya lapangan kerja di negara-negara lain bagi tenaga-tenaga terdidik Indonesia yang professional, dengan lingkungan kerja dan imbalan yang mungkin jauh lebih menarik daripada di Indonesia. Sebaliknya, tenaga-tenaga terdidik asing akan berdatangan di Indonesia dengan kemamuan profesionalisme yang tinggi, sehingga dengan kemampuannya itu mereka dapat menguras kekayaan sumber daya alam Indonesia.

Generasi muda Indonesia yang terdidik, dengan berlandaskan cinta Tanah Air yang mendalam, tidak akan membiarkan keadaan tersebut di atas berlarut, karena hal itu akhirnya akan membawa kepada penjajahan dalam bentuk lain, yaitu penjajahan melalui kegiatan ekonomi dan budaya. 


\section{Iman dan Taqwa Terhadap Tuhan Yang Maha Esa}

Sesuai dengan filsafat bangsa dan negara, pancasila, iman dan taqwa terhadap Tuhan Yang Maha Esa senantiasa perlu dilaksanakan oleh setiap insan Indonesia. Pendidikan nasional di Indonesia memberikan landasan kepada pengembangan iman dan taqwa terhadap Tuhan Yang Maha Esa sebagaimana tercantum dalam Undang-Undang Nomor 20 tahun 2003 tentang Sistem Pendidikan Nasional, bahwa pendidikan nasional bertujuan mencerdaskan kehidupan bangsa dan manusia Indonesia seutuhnya, yaitu manusia yang beriman dan bertaqwa terhadap Tuhan Yang Maha Esa, dan berbudi pekerti luhur, memiliki pengetahuan danketerampilan, kesehatan jasmani dan rohani, kepribadian yang mantap dan mandiri serta rasa tanggung jawab kemasyarakatan dan kebangsaan. Ketentuan tersebut dijabarkan lebih lanjut dalam peraturan-peraturan pemerintah yang bersangkutan.

Iman dan taqwa terhadap Tuhan Yang Maha Esa membawa konsekuensi kepada pelaksanaan ajaran-Nya, mematuhi petunjuk-Nya dan menjauhi larangan-Nya. Sehingga dalam menghadapi arus informasi canggih yang masuk ke ruang setiap rumah, terutama yang datanya dari luar negeri dengan pola budaya yang berbeda, yang dampaknya tidak selalu positif, maka iman dan taqwa merupakan alat penapis yang ampuh bagi tiap-tiap insane Indonesia. Dalam pengembangan Iptek, cendekiawan Indonesia dalam melaksanakan penelitiannya tidak dapat menganut "the sky is the limit" sebagaimana berlaku bagi cendekiawan di Barat, yang berarti tidak ada batas bagi penelitian dan penerapannya, sehingga apa pun dapat diteliti dan diterapkannya.

Batas bagi cendekiawan Indonesia adalah sebagaimana tercantum dalam ajaran Tuhan Yang Maha Esa melalui agama masing-masing, yang diperkuat oleh sila pertama Pancasila. Dengan demikian IPTEK di Indonesia harus disertai iaman dan taqwa (Imtaq). Dari sudut inilah pendidikan agama dan pendidikan Pancasila di sekolah amat penting fungsinya, yang pelaksanaannya disesuaikan dengan kemampuan persepsi anak didik, mulai sekolah dasar sampai dengan perguruan tinggi.

\section{Sikap Keterbukaan, Kebersamaan, dan Kemitraan}

Dari pengalaman yang amat banyak serta beragam dari generasi muda sebelumnya, telah berkembang keyakinan akan perlu dikembangkannya sikap keterbukaan, kebersamaan, dan kemitraan (K3). Sikap keterbukaan adalah (a state of mind), yang berkembang secara bertahap, tidak datang dengan tiba-tiba. Sikap keterbukaan adalah sikap membuka diri pada orang lain dalam interaksi personal. Sikap membuka diri ini berarti adanya kesediaan untuk mendengarkan orang atau pengapat lain.

Kewajiban pemimin untuk mau mendengarkan pendapat orang lain perlu dibudayakan dimasyarakat kita. Hal ini berkenaan denga pengakuan adanya hak berbicara bagi masyarakat yang dijamin dalam Undang-Undang Dasar 1945, sehingga aspirasi masyarakat benar-benar dapat dipahami oleh pemimpin. Ini merupakan langkah penting dalam proses pengambilan keputusan. Keputusan yang diambil oleh pemimpin dengan memperhatikan aspirasi masyarakat, yang diperoleh 
melalui interaksi pemimpin dengan masyarakat, akan meningkatkan kesediaan masyarakat untuk menerima dan melaksanakan keputusan, karena keputusan itu merefleksikan keinginan masyarakat.

Sikap kebersamaan didasarkan atas keyakinan bahwa pemecahan masalah secara bersama selalu lebih baik daripada dipecahkan sendiri. Masalah pada dirinya bersifat kompleks, sehingga tidak mungkin dipecahkan satu disiplin ilmu, lebihlebih masalah pembangunan. Pembangunan mencakup bidang yang multi-kompleks, yang harus didekati dengan inter dan multidisipliner serta lintas-sektoral. Masalah yang dihadapi tidak pernah sama sepanjang masa, karena kendala-kendala yang dihadapi berbeda-beda sesuai dengan perbedaan waktu dan tempat. Dengan demikian pemecahannya pun tidak sama. Oleh Karena itu harus senantiasa diupayakan adanya alternatif pemecahan, sesuai dengan situasi dan kondisi yang dihadapi. Ini adalah tugas seorang cendekiawan, karena cendekiawan adalah seseorang yang mampu menginternalisasikan cara berpikir alternative, termasuk para mahasiswa sebagai cendekiawan muda.

Kebersamaan membawa kepada partisipasi pemikiran berbagai pihak yang menguntungkan bagi pengambilan keputusan yang bijaksana. Kebersamaan berkaitan pula dengan kebersamaan antara generasi tua dan generasi muda dengan dasar saling menghargai dan saling memeprcayai. Dalam keadaaan bagaimana pun, selalu terdapat keterkaitan antar generasi, karena tidak mungkin tiba-tiba timbul suatu generasi tanpa adanya generasi terdahulu. Generasi tua mempunyai pengalaman yang perlu dimanfaatkan sepenuhnya, sedangkan generasi muda dapat melahirkan konsep-konsep yang cemerlang. Perlu dipahami bahwa kearifan tidak dimonopoli oleh siapa pun, ia terdapat pada generasi tua maupun generasi muda, terdapat didaerah perkotaan maupun pedesaan.

Sikap kemitraan memandang orang lain sebagai mitra, sebagai sahabat. Perbedaan pendapat yang dating dari mitra diterima sebagai hal yang dapat memperluas wawasan dan oleh karena itu perbedaan pendapat merupakan hikmah. Perbedaan pendapat dalam konfrontasi mengeskalasikan konflik karena adanya keinginan untuk tetap mempertahankan pendapat, meski sebenarnya diakui bahwa pendapat orang lain itu lebih daripada pendapat sendiri. Akan tetapi karena datangnya dari lawan, maka pendapat tersebut harus terus ditentang dengan segala cara.

Jawaban atas pertanyaan apakah seseorang mempunyai sikap K3 sebagaimana diuraikan di atas hanyalan dapat dijawab oleh orang itu sendiri. Ini adalah pertanggungjawaban moral terhadap diri sendiri dan terhadap Tuhan Yang Maha Esa.

\section{Sikap Budaya Harmoni}

Sikap budaya Indonesia yang sama dalam semua kebudayaan Indonesia adalah bahwa manusia Indonesia menegakkan harmoni dalam hubungannya dengan alam semesta dan masyarakat. Harmoni atau keselarasan istilah yang tergambar dalam Pancasila berupa Ketuhanan Yang Maha Esa, Kemanusiaan yang Adil dan Beradab, Persatuan Indonesia, Kerkyatan yang Dipimpin oleh Hikmat Kebijaksanaan Dalam Permusyawatan/Perwakilan, dan 
Keadilan Sosial bagi Seluruh Rakyat Indonesia.

Sikap budaya harmoni banyak persamaannya dengan sikap budaya berbagai bangsa di Asia, antara lain Jepang yang juga menegakkan harmoni dalam segenap hubungan manusianya. Namun, sikap buday itu berbeda bahkan bertentangan dengan sikap budaya dengan sikap budaya dunia Barat yang sejak Renaissance di abad ke-15 mengmbil sikap budaya menaklukan alam (to conquer nature). Dengan sikap budaya itu dunia Barat mengembangkan ilmu pnegetahuan secara dramatis dan kehidupan dinamis yang memandang konflik sebagai jalan kemajuan. Berdasarkan ilmu pengetahuan Barat mengembangkan kehidupan materilnya dan kesanggupan meluaskan kekuasaan.

Jika sikap budaya harmoni memandang kebersamaan atau masyarakat sebagai pilar kehidupan maka sikap budaya Barat menganggap individu manusia sebagai nilai utama. Itu sebabnya dunia Barat menghasilkan individualisme dan liberalisme, diikuti materialisme yang bermuarah pada imperialisme dan kolonialisme. Sebagaimana dibuktikan sejarah sikap budaya harmoni bukan sesuatu yang pasif dan status quo. Itu terlihat dalam sejarah Indonesia dengan kesediaan menerima agama Hindu, Budha, diikuti Islam dan Kristen. Sikap budaya harmoni berusaha melihat segi positif barang luar untuk diambil dan diintegrasikan dengan miliknya sendiri

Namun pengambilan itu tidak membuang yang lama meski berbeda, tetapi dijaga kontonuitas keindonesiaan. Diterima Hindu tanpa membuang yang asli, yaitu animisme dan dinamisme, diterima Budha tidak menghilangkan Hindu begitu seterusnya. Itu sebabnya Raden Fatah sebagai pimpinan Kerajaan Islam Demak menyatakan bahwa Demak adalah kelanjutan Majapahit bukan perpanjangan suatu kerajaan Arab.

Sikap budaya harmonis adalah toleran. Itu dapat dilihat saat berbagai umat beragama yang berbeda, khususnya Islam dan Kristen, bereksistensi dengan baik dan penuh gotong royong antara pemeluknya

Ketika di Indonesia, dunia Barat dengan sikap budayanya bisa diimbangi budaya harmonis meski terjadi penjajahan dan praktik imperialism, kehidupan masyarakat Indonesia dapat terpelihara sesuai prinsip-prinsip harmoni, toleransi dan kontinuitas. ${ }^{9}$

\section{PENUTUP}

Bangsa Indonesia kini menghadapi tantangan yang jauh lebih rumit dibanding dengan keadaan sebelumnya. Tantangan yang dihadapi bangsa dan negara yang sedang membangun, di tengah-tengah arus globalisasi, sungguh tidaklah muda. Tantang tersebut harus dihadapi dengan kemampuan professional yang tinggi, dilandasi cinta tanah air yang mendalam serta iman dan taqwa terhadap Tuhan Yang Maha Esa. Generasi muda yang akan mengemban tugas kepemimpian, kiranya perlu memahami serta melaksanakan sikap

\footnotetext{
${ }^{9}$ Ibid,Kompas, Jumat 23 Juni 2006.
} 
keterbukaan, kebersamaan, dan kemitraan (K3), serta sikap budaya harmoni. Keempat sikap tersebut harus menjadi cara hidup pemimpin, kini maupun di masa mendatang.

Secara khusus penyelenggara negara harus berkomitmen untuk memberikan keteladanan kepada masyarakat luas guna menjaga kemurnian Ideologi Pancasila. Kita harus membangun kesadaran dan melawan apatisme.

\section{DAFTAR PUSTAKA}

Ahmad Syafii Maarif. 1997. Pancasila, Sejarah, dan Perkisaran Abad Menjelang Milenium ke-3. Jurnal Pusat Studi Pancasila Universitas Gadjah Mada No. 1. Th 1 Juli 1997

Edwar W. Said. 1993. Culture and Imperialism. New York: Alfredl A. Knopf.

Erich Fromm. 1968. The Revolution of Hope. New York: Harper \& Row

Etience Gilson. 1969. God and PhilosophyNew Heven and London: Yale University Press.

Karen Amstrong. 1993. A History of God, New York: Alfred A Knopf

Rene Descartes. 1976. Discourse on Method and the Meditation. Terjemahan. F.E. Sutclife. New York: Penguin Books

Roger Graudy. 1984. The Balance Sheet of Wester Philosophy", AlNahda. Vol 4 No 3. 1984/1404, 14 